\title{
Overcoming Insecurity in Competing for Jobs in the Pandemic Era
}

\author{
Danny Sanjaya Arfensia ${ }^{1}$, Atika Dian Ariana ${ }^{2}$, Danu Aji Nugroho ${ }^{3}$, Ichwan Cahyono ${ }^{4}$ \\ Nadhira Inastiti Raharjo ${ }^{5}$, Khoirunnisa ${ }^{6}$, Riris Ristiana ${ }^{7}$, Nono Hery Yoenanto $^{8}$, Rudi \\ Cahyono ${ }^{9}$ \\ 1,2,3,4,5,6,7,8,9Faculty of Psychology, Universitas Airlangga
}

Submitted 17 August 2021 Accepted 7 October 2021 Published 30 October 2021

\begin{abstract}
Limited job opportunities amidst high competition in job-seeking during the pandemic can create a sense of insecurity in competing for jobs. This study aimed to help individual overcome feelings of insecurity and increase confidence in competing for jobs in the pandemic era. The study used a psychoeducation program to improve Optimism and Confidence with Appreciative Inquiry approach. The intervention was held in virtual space, through a webinar that was attended by 33 participants. The data collection technique used a sampling technique. Data analysis was carried out using paired sample t-test. The result showed that there was a significant difference in the Optimistic dimension $(t=2.528 ; p=0.020)$ and there was a significant trend in the Confidence variable $(t=1.930 ; p=0.068)$. Psychoeducation with the application of the online learning model and Appreciative Inquiry approach can increase individual confidence, especially in the aspect of optimism.
\end{abstract}

Keywords: appreciative inquiry; graduates; insecure; job seekers; psychoeducation

In Indonesia, human resources are one of the important company assets, of which companies require quality human resources to compete and develop rapidly. The demand for the quality of the workforce continues to increase from year to year, so the competition for jobs for job seekers is also getting tougher. Even though job seekers have met these criteria, with many people seeking a job and limited employment opportunities, inequality has occurred which has increased the number of unemployed.

Data from the Acting Head of the Manpower Service (Disnaker) Achmad Zaini (in Ginanjar, 2020) revealed that of the many unemployed are college and vocational school graduates. These groups are often referred to as "ready to work". Data from the Surabaya City Manpower Office shows that since 2019, 2,591 people are unemployed (Wijayanto, 2020). This number is increasing due to the Coronavirus Disease 2019 (Covid-19) pandemic. From April to May 2020, which was included in the initial period of the Covid-19, 497 people were laid off and 1,594 people were laid off by the company where they worked previously. This situation has put many unemployed college and vocational high school graduates, coupled with the uncertain pandemic situation and worsening the financial conditions of each company, a phenomenon of anxiety arise in the last year 
students who are almost finishing their studies sourced from uncertainty about their future post-graduation.

Anxiety is a part of everyday life and almost every individual has experienced it, however at a certain stage it will be bad for health. Kartono (2005) revealed that anxiety is an unpleasant emotional reaction characterized by fear. The feeling of fear arises because of a threat or disturbance to an object that is still abstract and also subjective fear which is characterized by feelings of tension, worry, and so on. One form of anxiety that can occur in students is anxiety facing the employment world. Final semester students are often confused about what steps to take after graduating, students compete with many other scholars who have graduated earlier and are not working or are still unemployed. The limited job opportunities and high competition in getting a job can cause several negative impacts, such as anxiety.

Anxiety about whether or not someone faces the world of work does not come from general recognition. Therefore, it is hoped that if someone feels anxious about the limited job opportunities and realizes that he has to solve the problem, there will be initiatives, brilliant ideas to find breakthroughs to overcome the limitations of job opportunities due to the increasing level of job competition. One of the individual efforts to overcome the emergence of anxiety in the world of work is to have self-confidence (Perry, 2005). Perry (2005) revealed that self-confidence enables a person to overcome new challenges, believe in himself in difficult situations, cross barriers that hinder, accomplish things that the person has never done and bring out his talents and abilities to the fullest. Self-confidence gives a person the courage not to worry about the consequences of failure (Perry, 2005).

Findings from Suseno and Saputro's study (2010) showed that with the confidence of students who will later enter the world of work, they are increasingly able to express and implement their abilities and competencies after going through the education level so that when they have to face competition, students as the workforce productive ones are ready, not only in practice but also mentally. To improve students' confidence level in facing anxiety, this study provides psychoeducation as an intervention to students.

DeLucia-Waack (2006) stated that psychoeducation is the provision of intervention or prevention aimed at providing development of life skills and strategies for preventing psychological problems that affect behavior and using a cognitive-behavioral framework (DeLucia-Waack, 2006). Winzelberg (in Cash \& Pruzinsky, 2002) further stated that through psychoeducation, individuals will be taught to understand problems, identify, and change attitudes and behavior so that they become aware of the possible consequences if they do not change unwanted behavior). The purpose of psychoeducation is to prepare for the prevention of lack of education and psychological problems (Schneider \& Corey, 2006). Based on the results of research conducted by Istiqamah and 
Jalal (2020), the provision of psychoeducation can increase the subject's confidence in himself to be able to take the next steps.

An appreciative inquiry was adopted in the psychoeducation design. It is a coordinated approach to organizational change that utilizes reflection, introspection, and collaboration to harness collective power. Popularized by David Cooperrider (1987), Appreciative Inquiry is an approach that has proven successful in improving human resources in well-known organizations, companies, and NGOs, such as UNESCO, GTE, ILO, and the American Red Cross. Appreciative Inquiry has not been used widely in the field of education and thus, the researcher is interested in adopting the approach of appreciative inquiry to become one of the approaches in psychoeducation to overcome feelings of insecurity in competing for jobs in the pandemic era. In psychology, appreciative inquiry uses positive psychology as the basis for this approach, by looking at a person's positive strengths, not weaknesses, but not overriding the individual's weaknesses.

\section{Method}

\section{Design of the program}

This research is a psychoeducational program designed in the form of a webinar with duration of +120 minutes. The researchers designed psychoeducational materials based on Appreciative Inquiry approach (Copperrider, 1987), with the aim that everyone from an early age has an understanding of their potential, realizes their vision, achieves a level of self-satisfaction, and can decide and plan for the future for their welfare.

The Appreciative Inquiry aims to help someone to see the positive strengths they have and jointly build a vision by collaborating with the parties concerned to realize what that person's dream is. There are six reasons why it is relevant to use appreciative inquiry, including: (1) building relationships that allow people to be recognized in their relationship roles; (2) creating opportunities for people to be heard; (3) generate opportunities for people to dream and to share their dreams; (4) creating an environment where people can choose how they contribute; (5) make people more wise in choosing and support for action; (6) encourage and enable people to be positive.

Appreciative inquiry consists of four stages, each is outlined below:

1) Discovery stage entails individuals who learn to use this approach to better understand what they are like, from their shortcomings to their potentials.

2) Dream stage involves individuals who use this kind of learning model to be able to determine what their life goals are, be more optimistic in achieving them, and determine what steps will be taken.

3) Design stage invites individual learners to determine factors to create a change within themselves; such as: who plays an important role in the realization of 
change, what needs to be prepared to achieve a predetermined vision, and how the process must be followed to make it all work.

4) Destiny stage helps the individual to gain insight from the process that has been undertaken so far, therefore they can understand what evaluative factors can be useful in the future, and the person will be even more excited to enjoy the results of the changes made.

The four stages of appreciative inquiry are also spread into eight underlying principles, namely (1) constructivist principles; (2) principle of simultaneity; (3) poetic principles; (4) anticipatory principles; (5) positive principles; (6) wholeness principle; (7) enactment principle; (8) free-choice principle (Whitney \& Trosten-Bloom, 2010). The benefits of applying appreciative inquiry are optimizing the resources you have, improving self-confidence to take action to create meaningful actions, and building constructive relationships (Setiawan, 2016).

Psychoeducation applies the learning model Appreciative Inquiry consists of 4 stages which are further developed into 4 psychoeducational materials, namely: 1) "Know Yourself, Love Yourself" (Discovery), 2) "Becoming a Charming Graduate" (Dream), 3) "Planning the Future" (Design), and 4) "Achieving Goals With Confidence" (Destiny). These four modules were carried out one time with a series of activities in the form of pretest and posttest, lectures, reflections, some participants (voluntarily) explain the results of reflection, discussion and question, and answer conducted through application Zoom, which is a popular application for video conferencing. In Indonesia, human resources are one of the important company assets, of which companies require quality human resources to compete and develop rapidly. The demand for the quality of the workforce continues to increase over the years, so the competition for job seekers is also getting tougher. Even though job seekers have met these criteria, with many people seeking a job and limited employment opportunities, inequality has occurred which has increased the number of unemployed.

\section{Study participants}

There were 33 participants with an age range of 17 to 33 years-old participating in the program. These participants were recruited through a sampling technique where respondents who come and meet the sample selection criteria are included as psychoeducation participants. The specific criteria set by researchers in the selection of participants include: a graduate of the undergraduate study program (S-1) of any major who was looking for a job in the pandemic era; or an active undergraduate student (S-1) of any major, aged 18 to 40 years-old (early adults), and able to communicate in Indonesian. They were recruited through various social media, such as WhatsApp, LINE, 
Instagram, Facebook, Twitter, and LinkedIn which was carried out for 5 days before the implementation of psychoeducation. The profile of participants can be found in Table 1.

Table 1.

Profile of Webinar Participants

\begin{tabular}{lll}
\hline Aspect & N & $\%$ \\
\hline Gender & & \\
$\quad$ Male & 6 & 28.57 \\
Female & 15 & 71.43 \\
\hline Age & & \\
$\quad<21$ years-old & 9 & 42.86 \\
21-25 years-old & 10 & 47.62 \\
26-30 years-old & 1 & 4.76 \\
$>30$ years-old & 1 & 4.76 \\
\hline Personality type & & \\
Adventurer & 3 & 14.29 \\
Advocate & 3 & 14.29 \\
Architect & 1 & 4.76 \\
Campaigner & 1 & 4.76 \\
Commander & 1 & 4.76 \\
Consul & 1 & 4.76 \\
Defender & 6 & 28.57 \\
Executive & 1 & 4.76 \\
Logician & 1 & 4.76 \\
Mediator & 3 & 14.29 \\
& & \\
\hline
\end{tabular}

\section{Data collection and analysis method}

There were 3 types of evaluations carried out in the implementation of psychoeducation, these are an evaluation of the implementation of activities, evaluation at the level of knowledge, and evaluation at the level of attitude. In evaluating the level of knowledge, participants filled out the pretest and posttest about the material given during psychoeducation activities, while for the evaluation of the attitude level, participants filled out the pretest and posttest on the self-confidence scale. The pretest and posttest instruments given have gone through psychometric tests, the validity of the instruments is obtained through content validity tests using expert judgment.

To measure the level of self-confidence, the scale used was Cahyo's self-confidence scale (Pangestianto, 2018) in the form of a Likert scale consisting of 36 items compiled 
based on Lauster's (1992) theory which consists of five aspects, namely belief in selfability, optimistic, objective, responsible, and rational and realistic. The Likert scale has been tested for validity and reliability, the reliability of the scale is 0.946 and the validity index moves from 0.377 to 0.805 . The instrument is said to be valid if it has a validity of $\geq$ 0.30 (Azwar, 2012). According to Sujarwanto and Rusilowati (2015), the instrument is said to be reliable if the reliability coefficient is $\geq 0.6$, so based on the results of the validity and reliability tests carried out, the scale is declared valid and reliable. In the study, data processing and analysis were carried out using the method paired sample t-test.

\section{Results}

The implementation of this webinar was attended by 33 participants with an age range of 17 to 33 years-old. Of the total participants, a total of 21 people filled out the pretest and posttest completely so that 21 data could be analyzed. Comparison of the average scores of pretest and posttest participants showed an increase in the level of understanding of psychoeducational materials and an increase in self-confidence, both in total and per dimension. Details of the participants' scores can be seen in Table 2.

Table 2.

Comparison of the Average Pretest and Posttest

\begin{tabular}{lccc}
\hline $\begin{array}{c}\text { Variable } \\
\text { (Dimension) }\end{array}$ & Score Mean Pretest & $\begin{array}{c}\text { Score Mean } \\
\text { Posttest }\end{array}$ & $\begin{array}{c}\text { Score Mean } \\
\text { Acquisition }\end{array}$ \\
\hline Knowledge & 82.38 & 86.43 & 4.05 \\
Confidence & 113.19 & 117.14 & 3.95 \\
Confident & 20.57 & 21.24 & 0.67 \\
Optimistic & 24.38 & 26.19 & 1.81 \\
Objective & 23.09 & 23.62 & 0.53 \\
Responsibility & 24.71 & 25.14 & 0.43 \\
Rational & 20.42 & 20.95 & 0.53 \\
\hline
\end{tabular}

Statistical analysis with paired-sample t-test showed that the significant difference in the Optimistic dimension was $t=2.528$ and $p=0.020$. There is a significant trend in the self-confidence variable, namely $t=1.930$ and $p=0.068$. The results of the statistical test can be seen in Table 3. 
Table 3.

Results of T Test

\begin{tabular}{lcc}
\multicolumn{1}{c}{ Variable (Dimension) } & $\boldsymbol{T}$ & $\boldsymbol{P}$ \\
\hline Knowledge & 1.587 & 0.128 \\
Confidence & 1.930 & 0.068 \\
Confident & 1.726 & 0.100 \\
Optimistic & 2.528 & $\mathbf{0 . 0 2 0}$ \\
Objective & 1.046 & 0.308 \\
Responsibility & 0.756 & 0.459 \\
Rational & 1.078 & 0.294 \\
\hline
\end{tabular}

\section{Discussion}

Comparison of the acquisition scores showed an increase in scores posttest in the participants on the aspects of knowledge and self-confidence. There is an increase in selfconfidence scores, both in total and in each dimension. The results of the t-test showed a significant difference in scores on the Optimistic dimension. The results of this statistical test indicate that psychoeducation is effective in increasing participants' knowledge and confidence, especially in the optimistic aspect.

This finding supports the results of research by DeLucia-Waack (2006) which stated that a way to overcome feelings of insecurity, such as feelings of lack of confidence, is psychoeducation. In line with this, Winzelberg stated that psychoeducation can teach individuals to understand problems, identify, and change attitudes and behavior so that they become aware of the possible consequences if they do not change unwanted behavior (Cash \& Pruzinsky, 2002). The purpose of psychoeducation is to prevent the impact of lack of education and psychological problems (Schneider \& Corey, 2006). Istiqamah and Jalal (2020) also stated that providing psychoeducation can increase the subject's confidence in himself to take the next steps.

The Covid-19 pandemic has had an impact on all aspects of life. One of the factors that made the biggest changes was the uncertainty aspect of the pandemic, including when this situation would end and how to survive during a pandemic situation. Changes that are sudden and last for an uncertain duration can cause insecurity in individuals; similarly, for new graduates who want to find work. The Appreciative Inquiry approach is considered a relevant approach to overcome feelings of insecurity or insecurity in a pandemic situation (Armstrong et al., 2020). 
The framework of thinking in Appreciative Inquiry can direct individuals and systems to change negative thinking patterns to become more optimistic, live more responsibly, have faith in life goals. Appreciative Inquiry provides an opportunity for individuals to realign individual thinking and engagement in a way that will help individuals become more strategic, resilient, and strength-based in the future to facilitate positive and sustainable change; and thus emerge as better individuals, communities, and the world in the Covid-19 pandemic situation (Armstrong et al., 2020).

Increasing confidence in graduates is expected to be able to increase their confidence in achieving success in realizing their plans after graduation. As found by Suseno and Saputro (2010) that with the self-confidence of students who will later enter the world of work, they are increasingly able to express and implement their abilities and competencies after going through the education level, so that when they have to face competition, students as a workforce who productive is ready, not only in practice but also mentally. In the end, self-confidence enables a person to overcome new challenges, to believe in himself in difficult situations, to overcome obstacles, to accomplish things that the person has never done, and to bring out his talents and abilities to the fullest (Perry, 2005). This is a characteristic that is expected to be possessed by every graduate to be able to compete in the world of work, especially during the Covid-19 pandemic.

\section{Conclusion}

Psychoeducation through webinars with the application of the learning model Appreciative Inquiry can increase individual confidence, especially in the aspect of optimism. There was an increase in participants' knowledge of the material provided in psychoeducation, namely self-introduction (Discovery), identification of expectations (Dream), planning (Design), and taking concrete steps to realize the plan (Destiny). Several obstacles that arose during the implementation of psychoeducation became the input for improvement for the implementation of similar training in the future.

\section{Suggestion}

Based on the results obtained from the results of the study, it is recommended that educational institutions as candradimuka craters and places of learning for graduates should prepare graduates' self-confidence by providing informal education through courses or training in certain skills (hard skills), as well as through other activities. work internships in companies or institutions that provide opportunities to increase work experience (soft skills), monitoring and evaluating the teaching and learning process provided, and designing methods that not only focus on education but also provide 
opportunities to make contact with a real work environment so that graduates can overcome the insecurity they experience when competing for jobs.

\section{Acknowledgement}

The success of this research cannot be separated from the participation of all parties who have contributed directly or indirectly to its implementation. Thanks to the Faculty of Psychology, Universitas Airlangga for providing infrastructure during the research process. Without these parties, researchers would not be able to achieve the target of this study smoothly from beginning to end.

\section{Authors' Contribution}

DSA, ADA, AND, IC, NIR, and K designed and analyzed the data. DSA and K collected data by implementing the intervention. RR read, edited, and revised the manuscript. DSA, NHY, and RC read and approved the final version of the manuscript.

\section{Conflict of Interest}

The authors declare no conflicts of interest.

\section{Orcid ID}

Danny Sanjaya Arfensia 0000-0003-3228-7838

\section{References}

Armstrong, A. J., Holmes, C. M., \& Henning, D. (2020). A changing world, again. How Appreciative Inquiry can guide our growth. Social Sciences \& Humanities Open, 2(1), 100038. https://doi.org/10.1016/j.ssaho.2020.100038

Azwar, S. (2012). Penyusunan skala psikologi. Pustaka Pelajar.

Cash, T.F. \& Pruzinsky, T. (Eds.) (2002). Body image: A handbook of theory, research, and clinical practice. The Guilford Press.

Cooperrider, D. L. \& Srivastva, S. (1987). Appreciative inquiry in organizational life. In

Woodman, R. W. \& Pasmore, W.A. (Eds.). Research in organizational change and development (Vol. 1, pp. 129-169). JAI Press.

DeLucia-Waack, J. L. (2006). Leading psychoeducational groups for children and adolescents. Sage Publications. http://dx.doi.org/10.4135/9781452204291

Ginanjar, D. (2020). Di Surabaya, sebanyak 497 orang di-PHK dan 1.594 orang dirumahkan. Retrieved from https://www.jawapos.com/surabaya/04/06/2020/di-surabayasebanyak-497-orang-di-phk-dan-1-594-orang-dirumahkan/

Istiqamah, S. H. N. \& Jalal, N. M. (2020). Psikoedukasi kesiapan bekerja bagi mahasiswa. Prosiding Seminar Nasional Hasil Pengabdian Kepada Masyarakat.

Kartono, K. (2005). Psikologi abnormal. Alumni. 
Lauster. (1992). Tes kepribadian (Terjemahan D.H. Gulo). Bumi Aksara

Pangestianto, B. (2018). Hubungan kepercayaan diri dengan adversity quotient karyawan (pada frontliner BRI Tulungagung) (Unpublished bachelor thesis). Fakultas Psikologi, Universitas Muhammadiyah Malang

Perry, M. (2005). Confidence booster (pendongkrak kepercayaan diri). Erlangga

Saputro, N. D., \& Suseno, M. N. M. (2010). Hubungan antara kepercayaan diri dengan employability pada mahasiswa. Jurnal Psikohumanika, 3(1), 21-30.

Setiawan, B. (2014). Appreciative inquiry untuk meningkatkan efektivitas pelatihan. Retrieved from http://www.slideshare.net/bukik/appreciative-inquiry-dan-training

Sujarwanto \& Rusilowati. A. (2015). Pengembangan instrumen performance assessment berpendekatan scientific pada tema kalor dan perpindahannya. Journal Science Education, 4(1), 780-797.

Wijayanto (2020, 22 September). Tidak ada program unggulan, Disnaker klaim jumlah PHK turun. Retrieved on 30 Desember 2020 from https://radarsurabaya.jawapos.com/read/2020/09/22/215289/tak-ada-programunggulan-disnaker-klaim-jumlah-phk-turun

Whitney, D \& Trosten-Bloom, A. (2010). The power of appreciative inquiry a practical guide to positive change. Berret-Koehler Publishers. Inc.

Yunita, E. (2013). Hubungan antara kepercayaan diri dengan kecemasan menghadapi dunia kerja pada mahasiswa semester akhir Universitas Muhammadiyah Surakarta (Unpublished thesis). Fakultas Psikologi, Universitas Muhammadiyah Surakarta. 